IRA-International Journal of Applied Sciences ISSN 2455-4499; Vol.03, Issue 03 (2016)

Institute of Research Advances

http://research-advances.org/index.php/IRAJAS

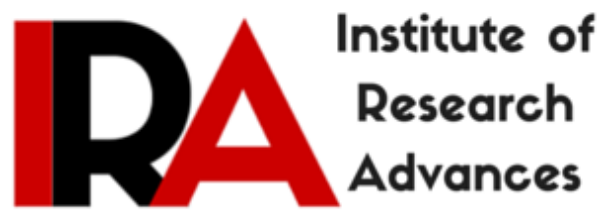

\title{
Detection of Root (Wilt) Disease of Coconut (Cocos nucifera L.) based on polyacrylamide gel electrophoresis
}

\author{
${ }^{1}$ V. K. Chaturvedi, ${ }^{2}$ G. Rajeev \& ${ }^{3}$ C. K. Nampoothiri \\ $\mathbf{1 , 2 , 3}$ ICAR-Central Plantation Crops Research Institute, Regional Station, \\ Kayamkulam,Krishnapuram-690533, Kerala, India.
}

DOI: http://dx.doi.org/10.21013/jas.v3.n3.p1

\section{How to cite this paper:}

Chaturvedi, V., Rajeev, G., \& Nampoothiri, C. (2016). Detection of Root (Wilt)

Disease of Coconut (Cocos nucifera L.) based on polyacrylamide gel electrophoresis.

IRA-International Journal of Applied Sciences (ISSN 2455-4499), 3(3).

doi:http://dx.doi.org/10.21013/jas.v3.n3.p1

(C) Institute of Research Advances

\section{(cc) EY-NC}

This works is licensed under a Creative Commons Attribution-Non Commercial 4.0 International License subject to proper citation to the publication source of the work.

Disclaimer: The scholarly papers as reviewed and published by the Institute of Research Advances (IRA) are the views and opinions of their respective authors and are not the views or opinions of the IRA. The IRA disclaims of any harm or loss caused due to the published content to any party. 


\begin{abstract}
Root (wilt) disease (RWD), caused by phytoplasma, is a major problem causing decreased coconut productivity in southern districts of Kerala and its bordering districts of Tamil Nadu in India. The disease is non-curable but its incidence can be reduced by propagating seedlings from nuts of disease free palms. The disease free palms are selected by ELISA test which uses antiserum obtained from rabbits against purified phytoplasma extract containing 29, 28 and $18.5 \mathrm{~K}$ Da proteins. With an objective of developing a simpler and easier biochemical test than ELISA for RWD detection in coconut, direct SDS PAGE profiles of soluble proteins from crude leaf extracts of healthy and diseased palms of West Coast Tall (susceptible), Chowghat Green Dwarf and Malayan Green Dwarf (high degree resistant) cultivars were evaluated for differences in intensities of protein bands with molecular masses corresponding closest to the purified phytoplasma extract proteins. It was found that the 31.2, 37.3, 16.9 and 13.8 KDa bands in WCT cultivar, 31 and 40.6 KDa in CGD cultivar and 29.9 and 37.1 KDa bands in the MGD cultivar showed consistent differences in intensities and/or presence or absence of certain bands between healthy and diseased palms. Correlations and path analysis relationship between intensity of different protein bands and ELISA value also showed significant association of one or two of these marker bands with ELISA values in each cultivar. The SDS PAGE profiles of crude leaf extracts could be used to effectively distinguish healthy and diseased RWD palms in these three cultivars.
\end{abstract}

Keywords: root (wilt) disease, coconut, detection, SDS PAGE

\title{
Introduction
}

Coconut is an important plantation crop grown in India over an area of 2.16 million hectares. India now has the largest area and production of coconut in the world producing about 18.4 million tons of coconut per annum. Kerala, Karnataka and Tamil Nadu States account for $80 \%$ of area and production in India..Root wilt disease (RWD) is a major yield constraint of coconut palms (Cocos nucifera L.) in southern districts of Kerala, and its bordering districts of Tamil Nadu, certain tracts in Goa and Karnataka. The disease is attributed to be caused by phytoplasma (Solomon et al., 1983). The disease is non curable, but manageable by providing proper nutrition, control of any associated leaf rot incidence, and by planting seedlings from disease free palms and disease tolerant varieties. Majority of coconut palms (98\%) in Kerala and other states are of the tall type (West Coast Tall), which is found to be relatively most susceptible to RWD. To a limited extent (about 1\%), the dwarf types especially the Chowghat Green Dwarf ( CGD) and the Malayan Green Dwarf (MGD) are grown, which have been found to have a high degree of resistance to RWD and are being recommended for cultivation. RWD free palms are selected based on absence of disease symptoms, a negative result in the enzyme linked immunosorbent assay (ELISA) test (Sasikala et al., 2010) and high yields. The ELISA test is based on use of antiserum obtained by injecting purified phytoplasma extract from RWD coconut palms into rabbits. The purified phytoplasma extract from root (wilt) diseased WCT palms was shown to contain three proteins with molecular masses of 29, 28 and 18.5 K Da but no such proteins in the purified phytoplasma extract from healthy WCT palms in an SDS PAGE study by Mayilvaganan et al., (2001). The ELISA test requires the preparation of purified phytoplasma extract, production of antiserum in rabbit and also has several steps in its procedure for carrying out the test. 
Jiang et al., (1988) had reported that unpurified soluble protein extracts of lettuce plant with mycoplasma disease gave a darker and wider band in SDS page as compared to healthy plant, at the same molecular mass position corresponding to the marker protein found in purified extract of mycoplasma from the diseased plant. It was of interest to find out whether the SDS PAGE patterns of unpurified extracts of soluble protein from healthy and root (wilt) diseased palms showed any potential differences in intensities in the bands closest to the three marker protein bands $(29,28$ and $18.5 \mathrm{KDa})$ of root (wilt) disease phytoplasma which could be used to differentiate between them. This would make the detection of root (wilt) disease palms simpler and easier than the ELISA test. Hence the present study was conducted, to determine the potential of SDS PAGE pattern of crude leaf extract of soluble proteins in distinguishing healthy from RWD palms of WCT, CGD and MGD cultivars and also to find out the changes in protein pattern of the palm in response to the disease.

\section{Material and Methods:}

Healthy and diseased palms of CGD (12-year old) and WCT (42- years old) were selected from I.C.A.R.-Central Plantation Crops Research Institute Regional Station Farm at Kayamkulam, the State Nursery farm at Karunagapally and from homestead gardens of farmers at Kottayam.TheMGD (22-year old) palms were selected from the Coconut Development Board Farm at Neriamangalam. These farms and gardens had palms of uniform age of each cultivar, although different for different cultivar, where different stages of RWD could be identified. The palms in each cultivar were categorized as healthy (no symptoms), disease early (less than $25 \%$ of leaves showing symptoms), disease middle (40 to $60 \%$ of leaves showing symptoms) and disease advanced (> 75\% of leaves showing symptoms). Selection of healthy and RWD palms were done based on the presence or absence of disease symptoms (leaflets flaccidity,yellowing and necrosis) and were confirmed by the ELISA test. At least 28 palms each of WCT and CGD cultivars, consisting of 7 palms each of the healthy and the three disease stages were selected. In MGD cultivar, 14 palms consisting of 7 healthy, 4 palms with slight symptoms of disease early, two distinct disease middle and one disease advanced palms were found and selected. For the ELISA test, six leaflets of spindle leaves were cut from each palm and transported between icepacks and then stored at $8-10{ }^{\circ} \mathrm{C}$ in a refrigerator. They were used for the test within 3 days after collection. Another such sample of six to twelve leaflets collected later in similar manner from confirmed healthy and diseased palms were stored in a freezer at $-50^{\circ} \mathrm{C}$ and used within 45 days after collection for extraction of soluble proteins. SDS PAGE patterns were determined in at least 4 different sets of 4 different plants of each of WCT, CGD and MGD cultivars. Each set consisted of one healthy, one disease early, one disease middle and one disease advanced category palm. However, in case of MGD, only one disease advanced palm available was repeated in all the 4 sets of different plants and one disease early and one disease middle palm were repeated in 2 out of the 4 sets of different palms that were studied in this cultivar.

For extraction of soluble protein of leaf, a simple procedure used for extraction of superoxide dismutase enzyme (Nishikimi et al., 1972), was followed with suitable modifications. SDS PAGE was carried out by the method of Laemmle (1970) with suitable modifications using a Bio-RAD mini vertical slab gel of $1.0 \mathrm{~mm}$ thickness. The separating gel contained $14 \%$ acrylamide and the stacking gel $4 \%$ acrylamide. Lower range molecular weight marker proteins standard in the molecular mass range $3.5 \mathrm{~K} \mathrm{Da}$ to $43.5 \mathrm{~K}$ Da obtained from Genei, Bangalore was used as protein ladder. Soluble protein 
was determined by the method of Lowry et al., (1951) The gels were run with equal volume and equal protein loads of the sample extracts. For equal volume 18 ul were loaded and for equal protein, volumes containing equal amount of protein in the range $30-56 \mu \mathrm{g}$. A constant current of $100 \mathrm{~V}$ was applied for 15 minutes for stacking protein and then increased to $180 \mathrm{~V}$ till the bromophenol blue dye front reached near the lower end of the separating gel (approximately 45 minutes). The bands were stained with coomassie brilliant blue. The gels were then viewed while in distilled water, over an incandescent light illuminator and the number of the bands and differences in band intensities in the healthy and diseased samples were recorded. The images of the protein bands in gel were taken using a BIO-RAD Gel Documentation Unit. Relative mobility (Rm) values of the protein bands of marker protein and leaf extract protein bands were determined by dividing the distance travelled in $\mathrm{cms}$ by the protein band, from the start point of separating gel, divided by the distance in $\mathrm{cms}$ travelled by the bromophenol dye front from the start point as before. The molecular mass of protein bands were determined using the linear regression equation obtained from the graph plotted between $\mathrm{Rm}$ values determined for the standard marker bands in each gel against $\log _{10}$ of their molecular masses. The intensity of each protein band in each lane of gel was scored visually using a scale consisting of six scores, 0 (no band), 1 (Light band ), 2 (dark band), 3 (darker band), 4 (more darker band), 5 (even more darker band) and 6 (darkest band visible). These observations were then used to distinguish differences in SDS PAGE profiles of healthy, disease early, disease middle and disease advanced palms.

The data of band intensity scores was statistically analyzed by the analysis of variance taking each gel as a replicate, with healthy and disease stages as main factors and protein bands as sub- factors. Significant differences at $\mathrm{P} \leq 0.05$ were determined by Duncan's multiple range tests (Rangaswamy, 2000). Correlation and path analysis (Mathur et al., 2008) were determined between band intensity scores for each protein band and ELISA reading of each of the palms for each variety.

\section{Results and Discussion:}

The SDS PAGE pattern showed 6 common protein bands (B1 to B5 and B8) in healthy and additional 2 variable bands (B6\&B7) in most of the diseased palms in WCT (Fig:1 and Table 1), 3 common protein bands (B3, B5 and B6) and three variable bands (B1, B2 and B4) in both healthy and diseased palms in CGD (Fig:2 and Table 2) five common protein bands (B1 to B5) in both healthy and diseased palms, with one middle and one advanced diseased palms exhibiting two to three additional bands (B6,B7 and B8) in the MGD cultivar (Fig:3 and Table 3). Based on the differences, in the number of common and variable protein bands, it was possible to differentiate between the three cultivars. Differences in certain comparable bands between dwarf and tall cultivars has been reported earlier ( Niral et al., 2007). The molecular

masses of the protein bands and the intensity scores of different bands in the three cultivars are presented in tables 1 to 3 . The molecular mass of protein bands varied from 10.1 to 67.8 in WCT, 31 to 72.1 in CGD and 11 to $69.7 \mathrm{KDa}$ in MGD cultivars respectively (Tables $1-3$ ). Based on the marker proteins identified in purified phytoplasma extract, the intensity scores of bands having molecular masses nearest to these RWD marker bands $(29,28$ and $18.5 \mathrm{kDa}$ ) were evaluated in the gels for differences between healthy and diseased palms. The bands nearest to these marker bands were $31.2 \mathrm{~K} \mathrm{Da}$ and 16.9 KDa bands in WCT, 31 K Da in CGD and 29.9 and 16.4 $\mathrm{K}$ Da bands in MGD (Tables 1-3). Examination of these bands in the three cultivars showed distinct and consistent differences in intensity between healthy and diseased 
palms. In WCT and CGD cultivars, the intensity scores of these bands were consistently and reproducibly higher in diseased palms as compared to healthy palms (Fig:1 to 2 and Table 1 to 2 ). This is in agreement with the ELISA test where absorbance values of about 0.25 to 0.5 or higher are observed for the healthy controls whereas palms having absorbance values greater than this cutoff value of control, are taken as diseased. But in the MGD cultivar, although the intensity scoring of this specific band was able to differentiate between healthy, middle and advanced diseased palms similar to the ELISA test, but it was not found to be in agreement with the ELISA test in differentiating between certain healthy and disease early palms (Fig.3 and Table 3). Both ELISA test and SDS PAGE method identified two palms (MGD12 and MGD-47) as healthy and (MGD-16 and MGD-20) as disease early. However, the ELISA test indicated palms No. MGD-9, as healthy and palms Nos. MGD-11 as disease early (Table 3), whereas the intensity scores of the $29.9 \mathrm{KDa}$ band indicated an exactly reverse result in case of these two palms (Table 3 Fig.3). This discrepancy in results between the ELISA and SDS PAGE in case of certain healthy and disease early palms of MGD might have been due to the little and borderline differences in symptoms that were present in these selected healthy and disease early palms available in the field. Due to this, it is likely that the differences might have been within the range of standard error or precision of the ELISA test as it is dependent on indirect estimation of the marker proteins through immunological reaction, colorimetric as well as the specific sample that is taken as the healthy control. In contrast to the ELISA test, the SDS PAGE method directly separates out the target marker and other proteins which are stained, and their intensities are assessed and the images are documented. Being a direct method, with less number of steps, the SDS PAGE method can be considered to be more precise than the ELISA test. In the present study, therefore, an intensity score equal to or less than 2 to $3,1.5$ and 2 to 3 respectively for the band with molecular mass in the 29.9 to $31.2 \mathrm{KDa}$ range can be used to identify the healthy palms of WCT, CGD and MGD respectively (Tables 1-3). In contrast, the band intensity scores equal to or greater than 3,2 and 3 can be used to identify root ( wilt) diseased palms of WCT, CGD and MGD respectively. In addition to this, the band with $16.9 \mathrm{KDa}$ mass with band intensity of 2 which was present in most of the diseased palms in WCT cultivar can be used to distinguish between healthy and diseased palms in this cultivar. The consistent presence of the $16.9 \mathrm{KDa}$ band representing one of the phytoplasma marker band $(18.5 \mathrm{KDa})$ in diseased palms of WCT, but not in the diseased palms in MGD and CGD, might be due to the genotypic differences in the expression of this band. In the SDS PAGE pattern of crude extract of aster yellow mycoplasma infected diseased lettuce plant, a major peptide bond (18.5 $\mathrm{KDa}$ ) was reported which was more prominent and wider than the corresponding band in healthy plants (Jiang et al., 1988). This band was also observed in purified extract of aster yellow mycoplasma from the diseased plant. The SDS PAGE profiles of soluble proteins between healthy and yellow mosaic disease infected leaves were reported to be slightly different in the genotypes Hibiscus cannabinus and Hibiscus sabdariffa (Chatterjee and Ghosh 2007). In the present study, apart from the marker bands, the palms exhibited two other protein bands having molecular masses 37.3 (B4) and 13.8 (B7) in the WCT (Fig: 1. Table 1.), the $40.6 \mathrm{~K}$ Da band (B4) in CGD (Fig: 2. Table 2.) and the $37.1 \mathrm{~K} \mathrm{Da}$ band (B5) in MGD (Fig: 3. Table 3) which showed distinct differences in intensity between healthy and diseased palms with high frequency and were found to be useful in addition to the marker bands in distinguishing healthy from root (wilt) diseased coconut palms. These proteins might have been up regulated in the plant in response to phytoplasma infection. Citrus aurantifolia plants infected with phytoplasma showed decreased intensity of some protein bands and exhibited two additional bands of 15 and $26 \mathrm{~K} \mathrm{Da}$ in the SDS PAGE pattern of infected leaves as compared to that of 
the healthy plants (Zafari et al., 2012). The method, described in this study, requires preliminary standardization using disease middle adult sample palms for optimizing the amount of protein in sample extract to be loaded to gel, to obtain intensities of discriminating bands (B4 to B7 in WCT, B4-B5 in CGD and B5-B6 in MGD) equal to that given in the figures (1 to 3 ) and for giving similar scores for band intensities as illustrated in the Tables $(1-3)$ corresponding to the band intensities observed in the three gels of the cultivars in the present study. The comassie brilliant blue staining solution should be prepared fresh on each day and used for staining not more than 1 or 2 gels on the same day. This method was tested using another 6 healthy and 18 diseased WCT adult palms using mini gels with 50ug protein load and maxi gels with 500ug protein load which indicated healthy palms to have band intensities of $\leq 3$ score for band B4and B5 and $\leq 1.5$ score for bands B6 and B7.These criteria could be used for differentiating healthy from RWD palms in WCT cultivar.

Comparison of mean intensities of protein bands are presented in Table 4. The potential discriminating bands B4-B7 in WCT, B5-B6 in CGD and B4-B5 in MGD had greater band intensities differences between healthy and diseased palms. Statistical relationships between band intensity scores and ELISA values for each cultivar are presented in table 4. Correlation analysis identified band B6 alone in WCT, band B5, B6 in CGD, band B4, B5 in MGD to be significantly associated with ELISA value. The results support the usefulness of band B6 in WCT; B5, B6 in CGD and B4, B5 in MGD in distinguishing between healthy and root (wilt) diseased palms in the three cultivars. Path analysis indicated that all the bands in the three cultivars, except B8 in WCT, to have direct effect on the ELISA value. It may be possible that small quantities of antibodies of all the protein bands in the three cultivars may also be present as impurities in the polyclonal antisera used in the ELISA test. However, path analysis indicated largest direct path coefficients for the band B6 in both WCT and CGD and the bands B5, B1 (direct) and B4 (indirect) in MGD (Table 4). Hence path analysis also indicated the usefulness of these bands in distinguishing healthy from the diseased palms. However, the band B1 in MGD was not found to be useful in distinguishing healthy and early diseased palms, although it had large path coefficient.

\section{Conlcusion:}

Differences in band intensities between healthy and diseased palms were prominent in the 31.2, 37.3, 16.9 and 13.8 KDa bands in WCT cultivar, 31 and 40.6 KDa in CGD cultivar and 29.9 and 37.1 in the MGD cultivar. The intensities and/or presence/absence of these particular bands could be utilized to effectively distinguish between healthy and RWD palms in the respective cultivars. The method does not require the purification of phytoplasma extract and use of rabbits to produce antiserum and has fewer steps in the test than the ELISA method, and therefore, is more precise. The method has additional advantages because it is also indicative of the cultivar being tested.

\section{Acknowledgment:}

The authors are grateful to the Director, Central Plantation Crops Research Institute, Kasaragod and Head, Central Plantation Crops Research Institute Regional Station, Kayamkulam for providing the necessary facilities for carrying out the research work. 


\section{REFERENCES}

Chatterjee A., \& Ghosh S. K. 2008. Alterations in biochemical components in mesta plants infected with yellow vein mosaic disease. Brazilian Journal of Plant Physiology 20: 267-275.

Jiang Y. P,, Lei J.D., and Chen T. A. 1988. Purification of aster yellows agent from diseased lettuce using affinity chromatography. Phytopathology 7:, 828-831.

Laemmli U. K. 1970. Cleavage of the structural proteins during the assembly of the head of bacteriophage T4. Nature 227: 680-685.

Lowry, O. H., Rosenbrough, N. J., Farr, A. L., \& Randall, R. J. (1951). Protein measurement with the Folin Phenol Reagent. J. Biol. Chem., 193: 265-275.

Mathur P. N., Muralidharan K., Parthasarathy V. A., Batugal P. and Bonnot F. 2008. Data analysis manual for coconut researchers. pp59-83.(www.bioversityinternational.org)

Mayilvaganan, M., Alka, G., \& Chithra, K. R. (2001). Biochemical evidences for purification of phytoplasma of root (wilt) disease of coconut. J ournal of Plant Biology, 28, 53-55.

Niral, V,, Geethalakshmi, P., \& Parthasarathy, V. A. (2007). Intrapopulation allelomorphism in tall and dwarf populations of the coconut. Acta Botanica Croatica, 66, $35-42$.

Nishikimi, M., Appaji. N., \& Yaqi, K .(1972). The occurrence of superoxide anion in the reaction of reduced phenazine methosulfate and molecular oxygen. Biochemical and. Biophysical Research Communications, 46, 849-854.

Rangaswamy, R. (2000). A text book of agricultural statistics. pp 260-263, 349-357. New Age International (P) Ltd., New Delhi-110002.

Solomon, J. J, Govindakutty, M. P., \& Nienhaus, F. (1983). Association of mycoplasma-like organisms with coconut root (wilt) disease in India. Z Pflkrankh Pflschutz, 90, 295-297.

Sasikala, M., Rajeev, G., Prakash, V. R., \& Amith, S. (2010). Modified protocol of ELISA for rapid detection of coconut root (wilt) disease. Journal of Plantation Crops, 38, 16-19.

Zafari, S,, Niknam. V., Musetti, R., \& Noorbakhsh, S. N. (2012). Effect of phytoplasma infection on metabolite content and antioxidant enzyme activity in lime (Citrus aurantifolia). Acta Physiologia Plantarum, 3, 561-568. 
Fig: 1. SDS PAGE protein pattern of healthy and root (wilt) diseased WCT adult palms

(Equal protein load, Gel No.1 of Table 1.)

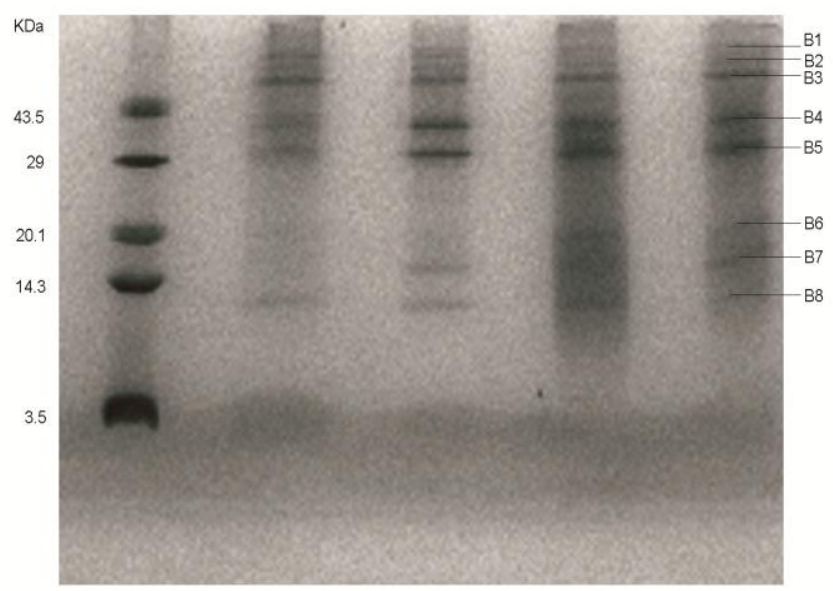

M H DE DM DA

M - Marker, H - Healthy, DE - Disease early, DM - Disease middle,

DA - Disease advanced, KDa -Kilo Daltons, B1-B8 -Band Numbers.

Table: 1. Characteristics of SDS PAGE protein bands of healthy and root (wilt) diseased palms of WCT cultivar (equal protein loaded)

\begin{tabular}{|c|c|c|c|c|c|c|}
\hline \multirow{4}{*}{$\begin{array}{l}\text { Gel } \\
\text { Number }\end{array}$} & \multirow{4}{*}{$\begin{array}{l}\text { Band } \\
\text { Number }\end{array}$} & \multirow{4}{*}{$\begin{array}{l}\text { Average } \\
\text { molecular mass } \\
\text { in KDa } \pm \\
\text { standard } \\
\text { deviation }(n=20 \\
\text { to } 32)\end{array}$} & \multicolumn{4}{|c|}{ Sample category and identity code } \\
\hline & & & Healthy & $\begin{array}{l}\text { Disease } \\
\text { Early }\end{array}$ & $\begin{array}{l}\text { Disease } \\
\text { Middle }\end{array}$ & $\begin{array}{l}\text { Disease } \\
\text { Advanced }\end{array}$ \\
\hline & & & \multicolumn{4}{|c|}{ Band Intensities (visually scored) ${ }^{\circledR}$} \\
\hline & & & $\begin{array}{l}\text { KTM-9 \& } \\
\text { (range in } \\
\text { other } 3 \\
\text { palms) }\end{array}$ & $\begin{array}{l}\text { WCT-237 \& } \\
\text { (range in } \\
\text { other } 3 \text { palms) }\end{array}$ & $\begin{array}{l}\text { WCT-206 \& } \\
\text { (range in other } \\
3 \text { palms) }\end{array}$ & $\begin{array}{l}\text { WCT-19 \& } \\
\text { (range in } \\
\text { other } 3 \\
\text { palms) }\end{array}$ \\
\hline \multirow{8}{*}{$\begin{array}{l}\quad 1 \\
\text { (Refer } \\
\text { Fig.1) }\end{array}$} & 1 & $67.8 \pm 3.8$ & 2 to 2 & 2 to2 & 2 to 2 & 2 to 1 \\
\hline & 2 & $61.7 \pm 4.2$ & 2 to 1 & 2 to 2 & 2 to 2 & 2 to 2 \\
\hline & 3 & $54.9 \pm 3.9$ & 3 to 2 & 3 to 4 & 3 to 3 & 3 to 3 \\
\hline & 4 & $37.3 \pm 2.1$ & 2 to 3 & 4 to 3 & 4 to 3 & 4 to 3 \\
\hline & 5 & $31.2 \pm 2.5$ & 2 to 3 & 4 to 3 & 4 to 3 & 4 to 3 \\
\hline & 6 & $16.9 \pm 1.4$ & O to 0 & 0 to 2 & 3 to 1 & 2 to 1 to 3 \\
\hline & 7 & $13.8 \pm 1.2$ & 0 to 0 & 2 to 0 & 3 to 1 & 3 to 1 \\
\hline & 8 & $10.1 \pm 1.2$ & 2 to 0 & 2 to 1 to 3 & 3 to 1 & 2 to 1 to 3 \\
\hline
\end{tabular}

${ }^{\circledR}$ No Band - Score 0, Light Band- Score 1, Dark Band- Score 2, Darker Band-Score 3, More Darker Band-Score 4 
Fig: 2. SDS PAGE protein pattern of healthy and root (wilt) diseased CGD adult palms

(Equal protein load, Gel No.1 of Table 2)

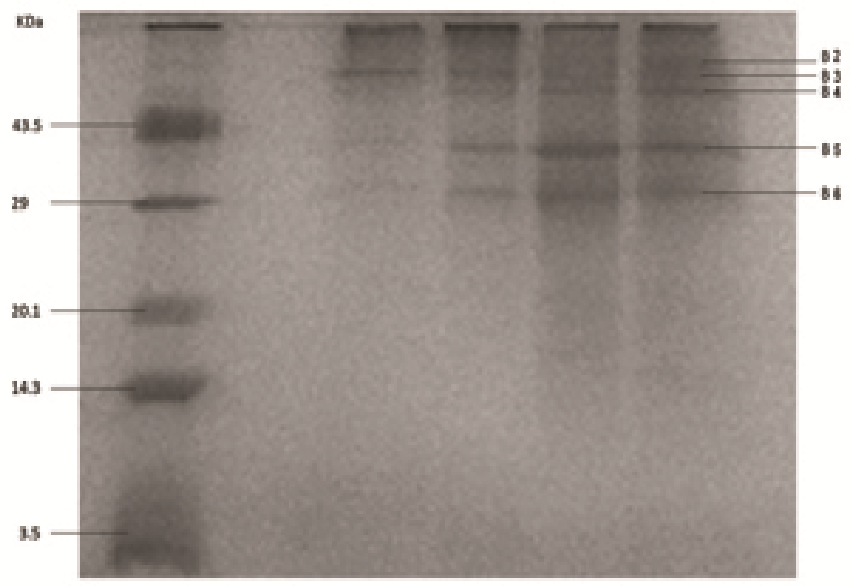

$\begin{array}{lllll}M & \text { H } & \text { DE } & \text { DM } & \text { DA }\end{array}$

M - Marker, H - Healthy, DE - Disease early, DM - Disease middle, DA - Disease advanced, KDa -Kilo Daltons, B1-B5 -Band Numbers.

Table 2. Characteristics of SDS PAGE protein bands of healthy and root (wilt) diseased palms of CGD cultivar (equal protein loaded)

\begin{tabular}{|c|c|c|c|c|c|c|}
\hline \multirow{4}{*}{$\begin{array}{c}\text { Gel } \\
\text { Number }\end{array}$} & \multirow{4}{*}{$\begin{array}{l}\text { Band } \\
\text { Number }\end{array}$} & \multirow{4}{*}{$\begin{array}{l}\text { Average } \\
\text { molecular } \\
\text { mass in KDa } \pm \\
\text { standard } \\
\text { deviation } \\
(\mathrm{n}=\mathbf{2 0} \text { to } \\
\mathbf{3 2})\end{array}$} & \multicolumn{4}{|c|}{ Sample category and identity code } \\
\hline & & & Healthy & $\begin{array}{l}\text { isease } \\
\text { arly }\end{array}$ & $\begin{array}{l}\text { Disease } \\
\text { Middle }\end{array}$ & $\begin{array}{l}\text { Disease } \\
\text { Advanced }\end{array}$ \\
\hline & & & \multicolumn{4}{|c|}{ Band intensities (visually scored) ${ }^{@}$} \\
\hline & & & $\begin{array}{c}\text { CGD-223 \& } \\
\text { (range in } \\
\text { other } 3 \\
\text { palms) }\end{array}$ & $\begin{array}{c}\text { CGD-1 \& } \\
\text { (range in } \\
\text { other } 3 \\
\text { palms) }\end{array}$ & $\begin{array}{c}\text { CGD-2 \& } \\
\text { (range in } \\
\text { other } 3 \text { palms) }\end{array}$ & $\begin{array}{c}\text { CGD-13 \& } \\
\text { (range in other } \\
3 \text { palms) }\end{array}$ \\
\hline \multirow{6}{*}{$\begin{array}{c}\text { I } \\
\text { (refer Fig.2) }\end{array}$} & 1 & $72.1 \pm 2.2$ & 0 to 3 & 0 to 0 & 0 to 2 & 0 to 3 \\
\hline & 2 & $67.6 \pm 8.9$ & 0 to 3 & 0 to 3 & 1 to 0 to 3 & 2 to 0 to 3 \\
\hline & 3 & $61.6 \pm 8.1$ & 2 to 3 & 2 to 4 & 1 to 4 & 2 to 3 \\
\hline & 4 & $55.0 \pm 6.6$ & 0 to 2 & 1 to 4 & 2 to 4 & 2 to 3 \\
\hline & 5 & $40.6 \pm 8.0$ & 1 to 1.5 & 2 to 4 & 3 to 1 to 4 & 3 to 6 \\
\hline & 6 & $31.0 \pm 3.2$ & 1 to 1.5 & 2 to 4 & 3 to 2 to 4 & 3 to 6 \\
\hline
\end{tabular}

${ }^{\circledR}$ No band - Score 0, Light band- Score 1, Dark band- Score 2, Darker band-Score 3, More Darker band-Sc ore 4, Darker band Score 5 and Darkest Band-Score 6. 
Fig: 3. SDS PAGE protein pattern of healthy and root (wilt) diseased MGD adult palms

(Equal protein load, Gel No.3 of Table 1.)

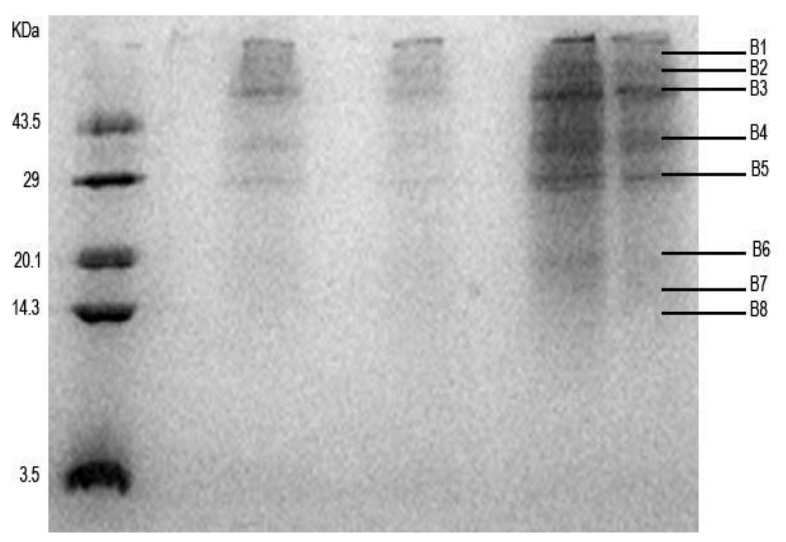

M $\quad$ H $\quad$ DE $\quad$ DM DA

M - Marker, H - Healthy, DE - Disease early, DM - Disease middle,

DA - Disease advanced, KDa -Kilo Daltons, B1-B8 -Band Numbers.

Table 3. Characteristics of SDS PAGE protein bands of healthy and root (wilt) diseased palms of MGD cultivar (equal protein loaded)

\begin{tabular}{|c|c|c|c|c|c|c|}
\hline \multirow{4}{*}{$\begin{array}{l}\text { Gel } \\
\text { Number }\end{array}$} & \multirow{4}{*}{$\begin{array}{l}\text { Band } \\
\text { Number }\end{array}$} & \multirow{4}{*}{$\begin{array}{l}\text { Average } \\
\text { molecular mass } \\
\text { in KDa } \pm \\
\text { standard } \\
\text { deviation }(n=4 \text { to } \\
32)\end{array}$} & \multicolumn{4}{|c|}{ Sample category and identity code } \\
\hline & & & Healthy & $\begin{array}{l}\text { Disease } \\
\text { Early }\end{array}$ & $\begin{array}{l}\text { Disease } \\
\text { Middle }\end{array}$ & $\begin{array}{l}\text { Disease } \\
\text { Advanced }\end{array}$ \\
\hline & & & $\begin{array}{l}\text { MGD-9 \& } \\
\text { (range in } \\
\text { other } 3 \\
\text { palms) }\end{array}$ & $\begin{array}{l}\text { MGD-11 \& } \\
\text { (range in } \\
\text { other } 2 \text { palms) }\end{array}$ & $\begin{array}{l}\text { MGD-75 \& } \\
\text { (range in other } \\
1 \text { palm) }\end{array}$ & MGD-78 \\
\hline & & & \multicolumn{4}{|c|}{ Band intensities (visually scored) ${ }^{@}$} \\
\hline \multirow{8}{*}{$\begin{array}{c}\text { I } \\
\text { (ref.Fig.3) }\end{array}$} & 1 & $69.7 \pm 6.4$ & 2 to 2 & 2 to 2 & 3 to 2 to 4 & 3 to 3 \\
\hline & 2 & $64.3 \pm 6.8$ & 2 to 1 & 2 to 1 & 2 to 1 & 2 to 1 to 3 \\
\hline & 3 & $56.1 \pm 6.6$ & 3 to 2 & 2 to 3 & 4 to 2 & 4 to 3 \\
\hline & 4 & $37.1 \pm 4.5$ & 3 to 2 & 2 to 3 & 4 to 3 & 4 to 4 \\
\hline & 5 & $29.9 \pm 4.1$ & 3 to 2 & 2 to 3 & 4 to 3 & 4 to 4 \\
\hline & 6 & $16.4 \pm 1.6$ & 0 to 0 & 0 to 0 & 2 to 0 & 2 to 0 \\
\hline & 7 & $13.2 \pm 0.8$ & 0 to 0 & 0 to 0 & 2 to 0 & 2 to 0 \\
\hline & 8 & $11.0 \pm 0.3$ & 0 to 0 & 0 to 0 & 2 to 0 & 2 to 0 \\
\hline
\end{tabular}

${ }^{\circledR}$ No Band - Score 0, Light Band- Score 1, Dark Band- Score 2, Darker Band-Score 3, Darker Band-Score 4 
Table.4. Mean protein band intensity score of healthy and disease categories and relationship of band intensity scores with ELISA value

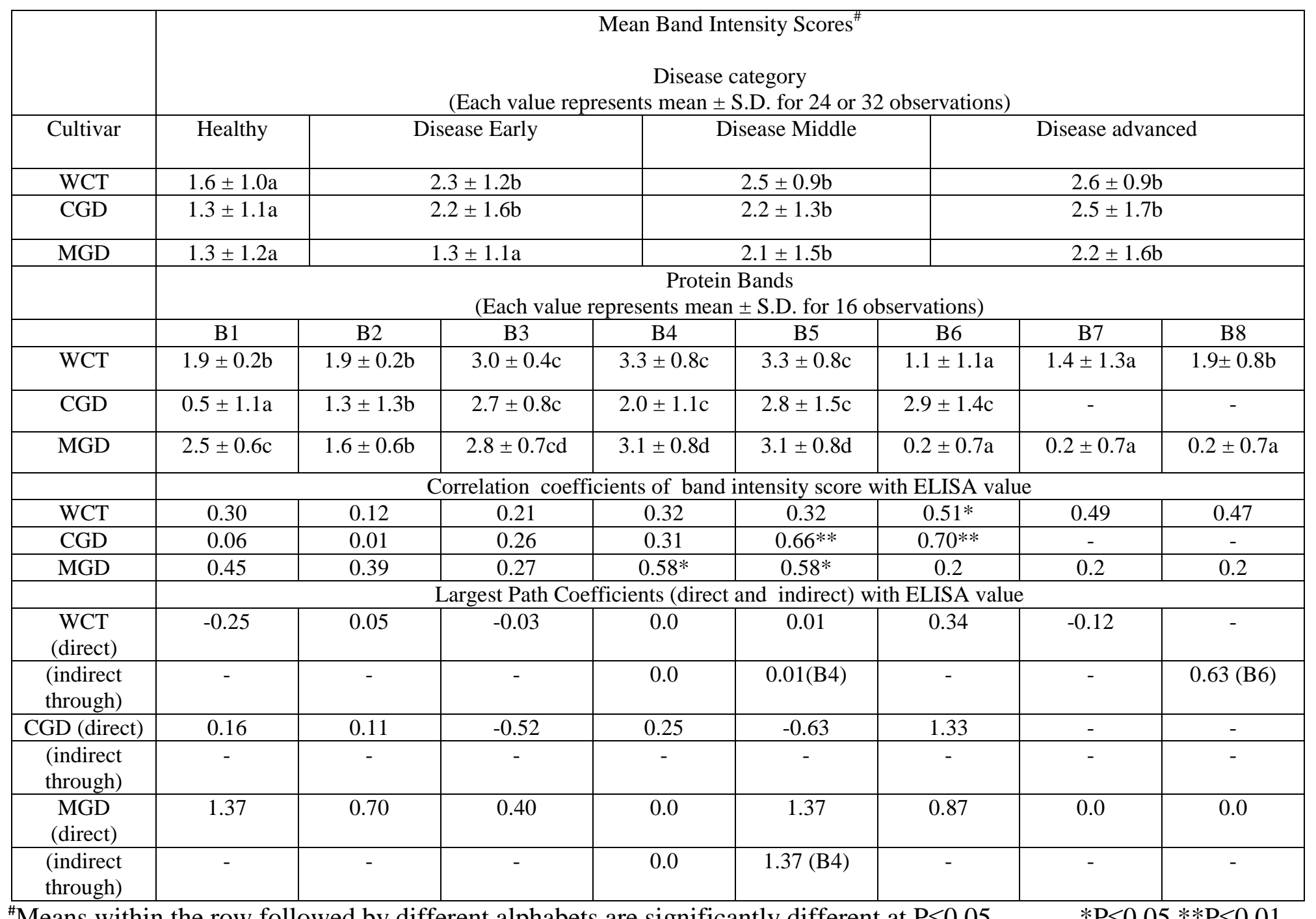

${ }^{\#}$ Means within the row followed by different alphabets are significantly different at $\mathrm{P} \leq 0.05$,

$* \mathrm{P} \leq 0.05, * * \mathrm{P} \leq 0.01$ 